\title{
Epstein-Barr virus in non-Hodgkin lymphoma of the tonsil in Indonesian patients
}

\author{
A.N.Kurniawan *, Meryanne Elizabeth *, Anthony S-Y Leong **
}

\begin{abstract}
Abstrak
Dua puluh kasus limfoma tonsil yang diperiksa di Bagian Patologi Anatomik, Fakultas Kedokteran Universitas Indonesia/Rumah Sakit Umum Pusat Nasional Dr Cipto Mangunkusumo, Jakarta, selama tahun 1995 - 1997 dipelajari secara klinikopatologik. Sediaan diperiksa secara histopatologik rutin, hibridisasi in situ dan imunohistokimia. Limfoma ditemukan paling banyak pada usia dekade ke 7, usia median ialah 57,5 tahun. Ratio laki dan perempuan ialah $1: 1$. Secara histologik limfoma derajat keganasan menengah 70\% dan limfoma derajat keganasan tinggi 30\%. Semua kasus limfoma tonsil ini merupakan limfoma sel B. Hasil pemeriksaan EBER dan LMPI semuanya negatif. (Med J Indones 2001; 10: 69-72)
\end{abstract}

\begin{abstract}
Twenty cases of tonsillar non-Hodgkin lymphoma seen at the Department of Anatomic Pathology, Faculty of Medicine, University of Indonesia during 1995 - 1997 were studied clinicopathologically. The specimens were analysed for routine histopathology, in situ hybridization and immunohistochemistry. The lymphoma was found mostly in the $7^{\text {th }}$ decade, the median age was 57.5 years. Male to female ratio was $1: 1$. The histologic types were $70 \%$ of intermediate grade and $30 \%$ of high grade of malignancy. All of the lymphomas were B cell lymphomas. EBER and LMP1 were not expressed in all cases.(Med J Indones 2001; 10: 69-72)
\end{abstract}

Keywords: tonsil lymphoma , clinicopathologic profile, immunophenotype, ebv

Hodgkin's lymphoma in the tonsil has been shown to be more prevalent than primary squamous cell carcinoma in Jakarta. ${ }^{1}$ The Epstein-Barr virus has been linked with several malignancies particularly those occuring in the head and neck, including nasopharyngeal carcinoma, Burkitt's lymphoma, Hodgkin's lymphoma, and T/NK cell lymphoma . As nasopharyngeal carcinoma is common in Indonesia, it raises the question whether the EBV might play a role in the tumorigenesis of tonsillar lymphoma. A clinico-pathologic study was conducted to examine the histologic type, immunophenotype and expression of EBV in cases of tonsillar lymphoma in Jakarta.

* Department of Anatomical Pathology, Faculty of Medicine, University of Indonesia/Dr. Cipto Mangunkusumo National Central General Hospital, Jakarta, Indonesia

** Hunter Area Pathology Services and Discipline of Anatomical Pathology, University of New Castle, New Castle, Australia

\section{MATERIALS AND METHODS}

Twenty cases of tonsillar lymphoma selected for adequacy of material which were diagnosed at the Department of Anatomic Pathology, Faculty of Medicine, University of Indonesia during 1995-1997 were studied. The histologic typing was done according to the updated Kiel classification. ${ }^{2}$ Immunohistochemical stains with the PAP method, using antibodies to CD45 RO (UCHL) and CD20 (L26) was employed. In situ hybridization for EBER, and immunostaining for LMP1 was done. The immunohistochemistry and in situ hybridization examination was done by one of the authors (A S-Y L). Clinical data was obtained from the hospital medical records (Dr. Cipto Mangunkusumo National Central General Hospital).

\section{RESULTS}

During the 3 years of study 68 cases of malignant tumor of the tonsil were found. There were 23 cases $(33,8 \%)$ of carcinoma and 45 cases $(66,2 \%)$ of non Hodgkin lymphoma. 
Twenty cases of lymphoma were studied by in situ hybridization and immunohistochemistry. The patients were between the third decade and eighth decade. The age distribution is shown in Table 1

Table 1. Age and histologic types of tonsillar lymphoma

\begin{tabular}{|c|c|c|c|c|c|c|}
\hline Age & 1 & 2 & 3 & 4 & 5 & 6 \\
\hline $0-9$ & - & - & - & - & - & - \\
\hline $10-19$ & - & - & - & - & - & - \\
\hline $20-29$ & - & - & - & - & 1 & - \\
\hline $30-39$ & - & - & - & 1 & - & - \\
\hline $40-49$ & . & - & 1 & 2 & 1 & - \\
\hline $50-59$ & - & 1 & 1 & 1 & - & 1 \\
\hline $60-69$ & . & 1 & 2 & 2 & 3 & - \\
\hline $70-79$ & - & 1 & - & 1 & - & - \\
\hline TOTAL & - & 3 & 4 & 7 & 5 & 1 \\
\hline Note: & \multicolumn{6}{|c|}{$\begin{array}{l}\text { 1: lymphocytic } \\
2: \text { centrocytic } \\
\text { 3: centrocytic-centroblastic } \\
\text { 4.: centroblastic } \\
5: \text { immunoblastic } \\
6: \text { lymphoblastic }\end{array}$} \\
\hline
\end{tabular}

The gender and histopathologic types are shown in Table 2

Table 2. Gender and histopathologic types of tonsillar lymphoma

\begin{tabular}{lllllll}
\hline Gender & 1 & 2 & 3 & 4 & 5 & 6 \\
\hline Male & - & 2 & 2 & 3 & 3 & - \\
Female & - & 1 & 2 & 4 & 2 & 1 \\
\hline TOTAL & 3 & 4 & 7 & 5 & 1 \\
\hline
\end{tabular}

Tonsillar lymphoma was found equally in men (10 cases) and women (10 cases). Clinically the patients presented with: lumps in the neck, dysphagia, headache, nasal congestion, reduced smell, tinnitus and diplopia. The duration of these symptoms and signs were between 3 weeks and 7 months. The involvement of lymphnodes in the neck was found in 13 cases (65\%), 6 was found ipsilateral and 7 cases bilateral. Only in 3 cases there were no neck lymphnode involvement, while in 4 cases no information was available.

The immunotyping and expression of EBV are shown in Table 3.
Table 3. Immunohistochemistry and in situ hybridization test in tonsillar lymphoma

\begin{tabular}{|c|c|c|c|c|c|c|}
\hline \multicolumn{2}{|c|}{ No. Age Sex } & \multirow{2}{*}{$\begin{array}{l}\text { Histologic type } \\
\text { CENTROBLASTIC }\end{array}$} & \multirow{2}{*}{$\frac{\mathrm{CD} 20}{+}$} & \multirow{2}{*}{ CD45RO } & \multirow{2}{*}{ EBER } & \multirow{2}{*}{ LMP1 } \\
\hline 1. 55 & F & & & & & \\
\hline 2. 70 & $\mathrm{~F}$ & CENTROBLASTIC & + & - & - & - \\
\hline 3. 63 & M & CENTROBLASTIC & + & - & - & - \\
\hline 4. 53 & $\mathrm{~F}$ & C.CYTIC-BLASTIC & + & - & - & - \\
\hline 5. 60 & M & CENTROCYTIC & + & - & - & - \\
\hline 6. 50 & $\mathrm{~F}$ & LYMPHOBLASTIC & + & + & - & - \\
\hline 7. 46 & M & IMMUNOBLASTIC & + & - & - & - \\
\hline 8. 60 & $\mathrm{~F}$ & CENTROBLASTIC & + & - & - & - \\
\hline 9. 29 & $F$ & IMMUNOBLASTIC & + & + & - & - \\
\hline 10. 70 & $\mathrm{~F}$ & CENTROCYTIC & + & + & - & - \\
\hline 11. 63 & M & C.CYTIC-BLASTIC & + & - & - & - \\
\hline 12. 43 & M & C.CYTIC-BLASTIC & + & - & - & - \\
\hline 13. 64 & $F$ & IMMUNOBLASTIC & + & + & - & - \\
\hline 14. 50 & M & CENTROCYTIC & + & + & - & - \\
\hline 15. 60 & M & IMMUNOBLASTIC & + & + & - & - \\
\hline 16. 65 & $\mathbf{F}$ & C.CYTIC-BLASTIC & + & + & - & - \\
\hline 17. 44 & M & CENTROBLASTIC & + & + & - & - \\
\hline 18. 63 & M & IMMUNOBLASTIC & : & + & - & - \\
\hline 19. 39 & $\mathbf{M}$ & CENTROBLASTIC & + & - & - & - \\
\hline 20. 40 & $\mathrm{~F}$ & CENTROBLASTIC & + & - & - & - \\
\hline
\end{tabular}

\section{DISCUSSION}

Data from the files of Department of Anatomic Pathology, Faculty of Medicine, University of Indonesia showed that cancer of the tonsil was only $1.08 \%$ of all cancers. Cancer of the tonsil comprised $3.6 \%$ of head and neck cancer, while head and neck cancer was $29.9 \%$ of all cancer. Of the oral and oropharyngeal cancers, cancer of the tonsil was second in frequency, after palate cancer.' Despite the low frequency of tonsil cancer, it is interesting to note that lymphoma in our hospital was more frequent than carcinoma. The ratio of lymphoma to carcinoma was $2: 1$. This data is not similar to reports in the Western literature, in which more than 90 percent of tonsil malignancies are squamous cell carcinomas. ${ }^{3}$ This dissimilarity poses the question, what is the reason for this difference and what factors may be operative ? Because of the prevalence of $\mathrm{EB}$ virus in the Indonesian community, we performed a clinicopathologic study to examine for possible relationship of EBV expression and tonsillar lymphoma.

The lymphoma was found mostly in the $7^{\text {th }}$ decade. The median age was 57.5 years. This finding was also reported by Shima et al. ${ }^{4}$ Lymphnode involvement in the neck was found in 13 out 20 cases (65\%). It was difficult to ascertain the clinical staging as there was no information of other lymphnodes in the chest or abdomen. Reports in the literature showed that three 
fourth of tonsillar lymphoma, were found in stage I or II when first presented. ${ }^{4,5}$

The histologic types of the lymphoma were 14 (70\%) intermediate grade (centrocytic, centroblastic-centrocytic and centroblastic) and $6(30 \%)$ were the high grade (immunoblastic and lymphoblastic). Lymphoma of the low grade type was not observed. Concurrent with reports from other centers, the majority of lymphoma were of the intermediate grade, ${ }^{4,5,6}$ although it has been reported that, among lymphomas of the head and neck, lymphomas of the tonsil were of the high grade. $^{7}$

All the cases reacted with CD20 (L26) antibody, indicating B cell lineage. This finding is in accordance with the report by Watson and Crocker ${ }^{8}$ who found that 20 out of 21 patients with palatine tonsil lymphoma were of the B cell origin. However, in 8 cases, positive reaction was also seen with CD45RO (UCHL-1) antibody, although not abundant. The reason for this is that they may be $T$ cells entrapped in the B lymphomas or possibly there was $\mathrm{T}$ cell activation in these tumors, particularly in high grade lymphomas, as coined by Wang et al. ${ }^{9}$ Out of these 8 cases in our series, 4 were of the high grade (3 immunoblastic and 1 lymphoblastic).

In this study, expression of Epstein-Barr virus, either EBER or LMP1, was negative in all cases. How would this compare with other reports? O' Leary and Kennedy ${ }^{10}$ in their study of sinonasal and Waldeyer's ring lymphoma found out that only 2 out 10 lymphoma in Waldeyer's ring (all of the large cell type) were positive for EBER, while EBER was negative for small cleaved cell lymphoma. Chan et $\mathrm{al}^{11}$ who investigated the strength of association of EBV with non-Hodgkin's lymphoma of the upper aerodigestive tract reported that among the 21 cases of lymphoma of tonsil and back of tongue none was EBER positive. They also showed that in the normal mucosa of nose/nasopharynx and tonsil only very rare EBER-positive small lymphocytes were found. This finding is in accordance with study done by Hirao et $\mathrm{al}^{12}$ who concluded that the palatine tonsil plays an important role in controlling EBV infection by the persistence of EBV-specific cellular immunity which efficiently eliminates EBV-transformed cells. Different finding was reported by Cirone et $\mathrm{al}^{1.3}$ who demonstrated by nested PCR technique that B lymphocytes in the germinal centers of tonsils of EBV seropositive individuals contain EBV DNA. However, study in children with tonsillar lymphoma done by Jevon et $\mathrm{al}^{14}$ showed that EBV is of little consequence in the pathogenesis of malignant lymphoma. Using PCR technique they detected EBV DNA in only 1 case out of 20 . In fact, study done by Ott et al ${ }^{15}$ suggested that among malignant lymphoma of the upper aerodigestive tract, EBV is not involved in lymphomagenesis of B cell tumors, but is associated with angiocentric T/NK cell lymphoma. These varied reports of the involvement of EBV in tonsillar lymphoma could be comprehended if we refer to the findings of Hardarson et $\mathrm{al}^{16}$ who did a study of the presence of EBV in many types of benign and malignant lymphoid lesions using PCR and a sensitive ISH method. They concluded that EBV may play a variety of roles in the development of malignant and non-malignant lymphoid lesions as they found a variable extent of EBV infection, from the low number until the abundant EBV+ cells.

The inapparent relationship of EBV involvement in our tonsillar lymphoma suggests that another route of etio-pathogenetic explanation needs to be sought. Concurrently, scientific explanation warrants clarification of the more prevalent lymphoma to carcinoma of the tonsil in Jakarta.

\section{SUMMARY AND CONCLUSION}

Twenty cases of tonsillar non-Hodgkin's lymphoma seen at the Department of Anatomic Pathology, Faculty of Medicine, University of Indonesia, Jakarta was analysed clinico-pathologically. The peak age incidence was the $7^{\text {th }}$ decade, the male to female ratio was 1:1. Sixty-five percent of cases showed neck lymphnode involvement. The histopathologic types if referred to the Working Formulation was $70 \%$ intermediate grade and $30 \%$ of the high grade malignancy. All tonsillar lymphoma in our study was of the B cell type.

None of the cases of tonsillar lymphoma showed EBV expression, and there is no explanation why lymphoma of the tonsil is more prevalent than carcinoma in Jakarta.

\section{REFERENCES}

1. Kurniawan AN. Pathology of tonsil malignancy. The $5^{\text {th }}$ Asean Otorhinolaryngological Head and Neck Congress. Jakarta, 1992. 
2. Chan JKC, Banks PM, Clearly ML, Delsol G, De Wolf Peeters C, Falini B. et al. A proposal for classification of lymphoid neoplasms (by the International Lymphoma Study Group). Histopathology 1994,25:517 - 36.

3. Guay ME, Lavertu P. Tonsillar carcinoma. Europ Arch Otorhinolaryngol 1995,252:259-64.

4. Shima N, Kobashi Y, Tsutsui K, Ogawa K, Maetani S, Nakashima Y, et al. Extranodal non-Hodgkin's lymphoma of the head and neck. A clinicopathologic study in the Kyoto-Nara area of Japan. Cancer 1990, 66:1190-7.

5. Hanna E, Wanamaker J, Adelstein D, Tubbs R, Lavertu P. Extranodal lymphomas of the head and neck. Arch Otolaryngol Head Neck Surg 1997, 123:1318-1323.

6. Barista I, Tekuzman G, Gullu I, Baltali E, Kars A, Ozisik $Y$, et al. Non- Hogkin's lymphomas of the tonsil: a retrospective analysis of twenty eight patients with primary tonsillary lymphoma. Tumori 1995, 81:234-7.

7. Neilly IJ, Dawson AA, Russell D, Laing MR. NonHodgkin's lymphoma of the head and neck: experience in the Grampian area. J Laryngol Otol 1990, 104: 972-5.

8. Watson MG, Crocker J. Non-Hogkin's lymphoma involving the tonsil: an immunohistochemical study. J Laryngol Otol 1991, 105: 445-50.

9. Wang J, Isaacson PG, Spencer J. Immunohistochemical analysis of $\mathrm{T}$ cell proliferation in normal tonsil and $\mathrm{B}$ cell lymphoma. J Clin Pathol 1995, 48; 873-5.
10. O'Leary G, Kennedy SM. Association of Epstein-Barr virus with sinonasal angiocentric $\mathrm{T}$ cell lymphoma. J Clin Pathol 1995; 48: 946-9. .

11. Chan JK, Yip TT, Tsang WY, Ng CS, Lau WH, Poon YF, et al. Detection of Epstein-Barr viral RNA in malignant lymphomas of the upper aerodigestive tract. Am J Surg Pathol 1994, 18: 938-46.

12. Hirao $M$, Harabuchi $Y$, Kataura $A$, Imai $S$, Osato $T$. Immunological role of human palatine tonsil in EpsteinBarr virus persistence. Acta Otolaryngol (Stockh) 1996, suppl 523: 158-60.

13. Cirone M, De Maria R, D' Alessandro A, Frati L, Faggioni A, Ragona G. Epstein-Barr virus DNA is present both in CD 10/CD 77 positive and negative subsets of human tonsillar lymphocytes. Cancer Lett 1995, 89:1,125-8.

14. Jevon GP, Elavathil LJ, Harnish DG, deSa DJ. Epstein-Barr virus in non- Hodgkin's lymphomas and lymphoid tissue in children. Pediatr Pathol Lab Med 1995, 15: 283-90.

15. Ott G, Kalla J, Ott MM, Muller Hermelink HK. The EpsteinBarr virus in malignant non-Hogkin's lymphoma of the upper aerodigestive tract. Diagn Mol Pathol 1997, 6:134-9.

16. Hardarson S, Anderson ME, Lutz CT. Presence of Epstein-Barr virus in many types of benign and malignant lymphoid lesions. Detection by polymerase chain reaction and in situ hybridization. Diagn Mol Pathol 1994;3:22-31. 